\title{
Adab Berhias Muslimah Perspektif Ma'nā-cum-Maghzā tentang Tabarruj dalam QS Al-Ahzab 33
}

\author{
Muslimah Dress Up Manner in the Ma'nā-cum-Maghzā Perspective \\ of Tabarruj in QS Al-Ahzab 33
}

\section{Mahfidhatul Khasanah}

Universitas Islam Negeri Sunan Kalijaga, Yogyakarta, Indonesia. $\underline{\text { mahfidhaa25@gmail.com }}$
Article history:

Submitted: 1 September 2021

Accepted: 11 December 2021

Published: 15 December 2021

\begin{abstract}
One of the intriguing issues in the Islamic study is about women. Qur'an is used as a way of life for humans because it is believed to include various rules regarding all aspects of their life, including on Muslimah dress up manner. Today, many women spend money on physical treatments. This shows that women are getting more and more excessive about how to dress up with the aim of a compliment and attract others which is contrary to the tabarruj prohibition in the QS Al-Ahzab 33. The formulation of the problem in this paper is how the historical meaning and significance and the 'dynamic significance' of the verse. Applying the ma'nā-cum-maghzā hermeneutics perspective, it can be concluded that tabarruj was a bad behavior of women who were excessively ornate in the jahiliyyah era and becomes relevant again at this time. Although the verse was revealed to the wives of the Prophet, it is relevant for all Muslim women until now because of its universal moral message. This paper concludes the dress up manner for Muslimah to avoid tabarruj, including avoiding the intention not to flaunt in front of non-mahram, using make up means as needed, dressing up with the aim of ibadah by reading basmalah and prayers.
\end{abstract} Keywords: dress up manner; ma'nā-cum-maghzā; muslimah; QS Al-Ahzab 33; tabarruj.

Abstrak: Salah satu isu yang menarik dalam kajian Islam adalah tentang perempuan. Al-Qur'an dijadikan pedoman hidup bagi manusia karena diyakini memuat berbagai aturan tentang segala aspek kehidupan, termasuk tentang tata cara berbusana bagi Muslimah. Saat ini, banyak wanita menghabiskan uang untuk perawatan fisik. Hal ini menunjukkan bahwa wanita semakin berlebihan dalam hal berdandan dengan tujuan untuk mendapat pujian dan menarik orang lain, yang mana hal ini bertentangan dengan larangan tabarruj dalam QS Al-Ahzab 33. Tulisan ini bertujuan mengungkap makna dan signifikansi historis serta makna dinamis ayat tersebut. Dengan menggunakan perspektif hermeneutika ma'na-cum-maghzāa, dapat disimpulkan bahwa tabarruj adalah perilaku buruk perempuan yang berhias secara berlebihan di era jahiliyyah dan menjadi relevan kembali saat ini. Meskipun ayat tersebut diturunkan kepada istri-istri Nabi, namun tetap relevan bagi semua wanita Muslim hingga saat ini karena pesan moralnya yang universal. Tulisan ini menyimpulkan adab berhias bagi muslimah untuk menghindari tabarruj, antara lain menghindari niat untuk tidak pamer di depan non-mahram, menggunakan make up sesuai kebutuhan tidak secara berlebihan, berdandan untuk tujuan ibadah dengan diawali membaca basmalah dan doa.

Kata kunci: adab berhias; ma 'nā-cum-maghzā; muslimah; QS Al-Ahzab 33; tabarruj. 


\section{Pendahuluan}

Isu menarik terkait diskursus Islam dan wanita adalah mengenai tabarruj. Berhias dan memakai perhiasan merupakan hal yang wajar dilakukan oleh wanita karena sudah menjadi fitrahnya setiap kaum hawa ingin tampil cantik dan elegan. Namun di samping itu, Islam juga memberikan batasan dan aturan-aturan tertentu dalam berhias. ${ }^{1}$ Untuk mendapatkan label cantik dari orang lain, seorang wanita pun berhias dan berpakaian dengan cara mereka. Bahkan tidak sedikit dari mereka yang mengambil jalan instan, misalnya dengan melakukan operasi plastik agar membuat apa yang dirasa kurang dari dirinya bisa sesuai keinginannya. Lebih ironis lagi, kecantikan yang mereka perjuangkan tersebut hanya bertujuan untuk dipamerkan di hadapan yang bukan mahram mereka, bukan di hadapan suami. ${ }^{2}$ Fenomena seperti ini menimbulkan kesan yang negatif dalam pandangan sosial di kehidupan bermasyarakat, di mana para wanita berlomba-lomba dalam urusan dunia sehingga lupa akan kehidupan akhirat, dengan tujuan ingin terlihat fashionable. ${ }^{3}$ Islam memandang fenomena seperti ini dinamakan tabarruj. Ash-Shiddieqy menjelaskan tabarruj yaitu perbuatan wanita yang memperlihatkan keindahan wajah dan tubuhnya serta menampakkan perhiasan dan kecantikannya kepada khalayak umum. ${ }^{4}$

Konsep tabarruj menimbulkan perbedaan penafsiran di kalangan para mufasir. Menurut Ibnu Katsir misalnya, tabarruj adalah wanita yang keluar rumah dengan berjalan di hadapan lelaki dengan maksud mengundang nafsu mereka. Tabarruj adalah menampakkan perhiasan dan kemolekan yang justru seharusnya ditutupi karena dapat mengundang syahwat lelaki. Pengertian tabarruj turut meliputi pengertian berjalan berlenggak-lenggok di hadapan lelaki seperti mempertontonkan rambut, serta perhiasan seperti kalung, permata, dan sejenisnya. ${ }^{5}$ Muhammad Hasan Al-Hamsi mendefinisikan tabbarruj berarti menampakkan perhiasan dan kecantikan yang wajib ditutup ${ }^{6}$ Ahmad Musthafa Al-Maraghi menyebutkan tabbarruj adalah wanita yang menampakkan sebagian kecantikannya yang seharusnya ia tutupi. ${ }^{7}$ Lebih spesifik, Sayid Sabiq menjelaskan tabbarruj mempunyai pengertian yang lebih spesifik, yaitu keluarnya wanita dari kesopanan dan menampakkan bagian-bagian tubuhnya yang dapat mengundang fitnah dan dengan sengaja mengumbar kecantikan. ${ }^{8}$ Perbedaan tentang makna tabarruj, bagaimanapun tidak bisa dilepaskan dari pemahaman mereka terhadap ayat-ayat al-Qur'an, salah satunya adalah QS al-Ahzab ayat 33 .

Dalam QS al-Ahzab ayat 33 dijelaskan bahwa Allah mengimbau agar istri-istri Rasulullah Saw berdiam diri di dalam rumah dan melarang mereka berhias sebagaimana wanita pada masa Jahiliah berhias serta memerintahkan mereka untuk mendirikan salat, menunaikan zakat dan menaati perintah Rasulullah Saw. Berpijak dari keterangan di atas, maka tulisan ini berusaha

${ }^{1}$ Muhammad Ibnu Muhammad Ali, "Hijab Risalah Tentang Aurat,” Yogyakarta: Pustaka Sufi, 2002.

2 Abdul Syukur Al-Azizi, Kitab Lengkap Dan Praktis Fiqh Wanita (NOKTAH, 2017).

${ }^{3}$ Vera Nur Azmi, "Makna Tabarruj Perspektif Hadits Dalam Kitab Syarah Shahih Muslim Karya Imam AnNawawi (631-676 H.)," Jurnal Penelitian Ilmu Ushuluddin 2, no. 2 (2022): 218-34, https://doi.org/10.15575/JPIU.13591.

4 Sudariyah Sudariyah, "Konstruksi Tafsir Al-Qur'anul Majid An-Nur Karya M Hasbi Ash-Shiddieqy," SHAHIH: Journal of Islamicate Multidisciplinary 3, no. 1 (June 10, 2018): 93-106, https://doi.org/10.22515/SHAHIH.V3I1.1282.

${ }^{5}$ Imad Zaki Al-Barudi, Tafsir Al-Qur'an Wanita (Pena Pundi Aksara, 2007).

6 Mirna Wati and Hasep Saputra, "The Concept of Tabarruj in the Qur'an According to Muslim Commentators," AJIS: Academic Journal of Islamic Studies 3, no. 2 (December 30, 2018): 163-90, https://doi.org/10.29240/AJIS.V3I2.577.

${ }^{7}$ Wati and Saputra.

${ }^{8}$ Wati and Saputra. 
mengkaji surah al-Ahzab ayat 33 dengan menggunakan pendekatan penafsiran yang bersifat dinamis dan kontekstual, salah satunya dengan menggunakan hermeneutika yang dicetuskan oleh Sahiron Syamsuddin yakni hermeneutika ma'nā-cum-maghzā. Pendekatan ini diharapkan dapat menjawab rumusan masalah dalam kajian ini, yaitu bagaimana makna historis surat al-Ahzab ayat 33, serta bagaimana makna historis tersebut dikontekstualisasikan untuk saat ini. Berbagai kajian terdahulu terkait konsep tabarruj dan sejenisnya sebenarnya sudah pernah dilakukan oleh beberapa peneliti, di antaranya Firmansyah ${ }^{9}$, Zuhrotul Afifah ${ }^{10}$, Muhammad Nuri Asikh ${ }^{11}$, Tezar Alfi Syahdan ${ }^{12}$, dan Sarimah Binti Nordin $(\mathrm{dkk})^{13}$.

Selanjutnya gambaran umum tentang teori hermeneutika yang akan penulis gunakan, hermenerutika ma'nā-cum-maghz $\bar{a}$ adalah pendekatan di mana penafsir menggali atau mereduksi makna dari ayat yang hendak ditafsirkan ( $m a$ 'n $\bar{a})$ dan pesan utama historis (maghzā) serta memperhatikan asbabun Nuzul ayat tersebut. Selanjutnya, mengembangkan signifikansi teks tersebut ke masa kini. Dari istilah tersebut, dapat disimpulkan bahwa ada tiga hal penting yang wajib diperhatikan jika hendak menggunakan pendekatan ini untuk menafsirkan ayat al-Qur'an, yaitu: (1) al-ma'nā al-tārikhī (makna historis), (2) al-maghzā al-tārikhī (signifikansi fenomenal historis) dan (3) al-maghzā al-mutaharrik (signifikansi fenomenal dinamis) untuk konteks ketika teks al-Qur'an ditafsirkan. ${ }^{14}$

Dalam menggali sebuah al-ma'nā al-tārikhī (makna historis) dan al-maghzā al-mutaharrik (signifikansi fenomenal historis), Sahiron memberikan langkah-langkah untuk prosesnya. Terkait penggalian makna historis seseorag perlu melakukan empat macam tindakan, diantaranya: (1) analisis bahasa baik kosakata ataupun strukturnya; (2) butuhnya mempertajam analisis dengan melakukan intratektualitas dalam arti untuk membandingkan dan menganalisis penggunaan kata yang sedang ditafsirkan dalam penggunaannya di ayat-ayat lain; (3) melakukan analisis intertekstualitas dengan cara menghubungkan dan membandingkan antara ayat al-Qur'an dengan teks-teks lain yang ada di al-Qur'an, jika memungkinkan; dan (4) memperhatikan konteks historis pewahyuan ayat-ayat al-Qur'an, baik bersifat mikro ataupun makro. ${ }^{15}$

Selanjutnya, untuk menggali al-maghzā al-tārikhī (signifikansi fenomenal historis), penafsir perlu melakukan beberapa langkah, antaranya: (1) menentukan kategori ayat, sebagian ulama membaginya menjadi menjadi tiga kategori besar yaitu ayat-ayat tentang ketauhidan, ayatayat tentang hukum, dan ayat-ayat yang berisi tentang nilai-nilai fundamental;

\footnotetext{
${ }^{9}$ F Firmansyah, "Konsep Tabarruj Dalam Hadis: Studi Tentang Kualitas Dan Pemahaman Hadis Mengenai Adab Berpakaian Bagi Wanita," AT-TAHDIS: Journal of Hadith Studies 1, no. 2 (July 1, 2017), http://jurnal.uinsu.ac.id/index.php/attahdits/article/view/711.

10 Zuhroful Afifah, "Tafsir Larangan Bersolek (Tabarruj) Dalam Surah Al-Ahzab: 33 Menurut at-Thabari" (UIN Sunan Ampel Surabaya, 2014).

11 Muhamad Nur Asikh, "Makna Tabarruj Menurut M. Quraish Shihab Dalam Tafsir Al-Mișbāh Dan Relevansinya Di Era Sekarang” (UIN Walisongo Semarang, 2018).

12 Tezar Alfi Syahdan, "Pemahaman Dan Pengalaman Mahasiswa Fakultas Ushuluddin Dan Filsafat UIN Syarif Hidayatullah Jakarta Tahun 2011 (Studi Kasus Hadis Tabarruj)” (UIN syarif Hidaytullah Jakarta : Fakultas Ushuluddin Dan Filsafat, 2011, 2011), https://repository.uinjkt.ac.id/dspace/handle/123456789/1457.

13 Sarimah binti Nordin, Sulaiman Shakib bin Mohd Noor, and Mohd Al'Ikhsan bin Ghazali, "Fenomena Tabarruj Masa Kini Dalam Kalangan Wanita Muslimah," in Proceedings of the International Conference on Education towards Global Peace, 2016.

14 Sahiron Syamsuddin, ed., Pendekatan Ma'na-Cum-Maghza Atas Al-Qur'an Dan Hadis: Menjawab Problematika Sosial Keagamaan Di Era Kontemporer (Yogyakarta: Asosiasi Ilmu Alquran \& Tafsir se-Indonesia, 2020), http://digilib.uin-suka.ac.id/id/eprint/40730/1/MAGNA CUM MAGHZA.pdf.

${ }^{15}$ Syamsuddin.
} 
mengembangkan hakekat atau definisi serta al-maghzā al-tārikhī (signifikansi fenomenal historis) untuk kepentingan dan kebutuhan pada konteks kekinian (waktu) serta kedisiniian (tempat) di mana atau ketika teks al-Qur'an itu ditafsirkan; (3) menangkap makna-makna simbolik ayat alQur'an; dan yang terakhir (4) berusaha mengembangkan penafsiran dengan menggunakan perspektif yang diharapkan lebih luas. ${ }^{16}$

Kajian tulisan ini tentu saja berbeda dengan kajian-kajian terdahulu yang telah penulis cantumkan di atas, di mana fokus kajiannya adalah usaha untuk mengkaji surah al-Ahzab ayat 33 dengan menggunakan pendekatan ma'nā-cum-maghzā untuk untuk kemudian menemukan ma'nā

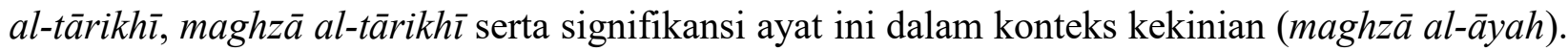
Tulisan ini diharapkan dapat memberikan pemahaman yang kontekstual dan holistik terkait konsep tabarruj yang terdapat dalam QS al-Ahzab ayat 33.

\section{Pembahasan}

\section{Analisis Linguistik}

Redaksi al-Qur'an surat al-Ahzab ayat 33 adalah sebagaimana berikut:

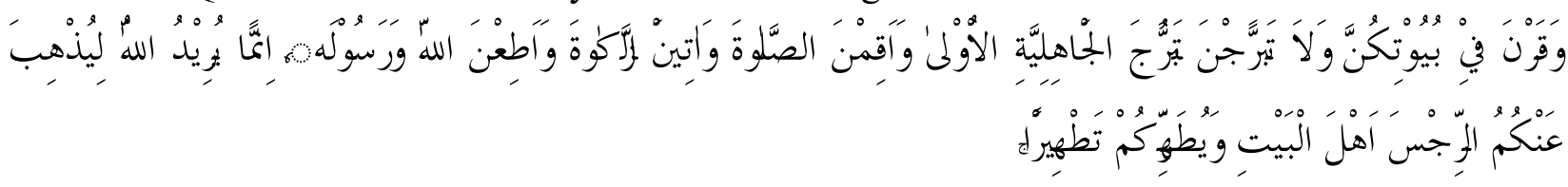

Artinya: "Tetaplah (tinggal) di rumah-rumahmu dan janganlah berhias (dan bertingkah laku) seperti orang-orang jahiliah dahulu. Tegakkanlah shalat, tunaikanlah zakat, serta taatilah Allah dan Rasul-Nya. Sesungguhnya Allah hanya hendak menghilangkan dosa darimu, wahai ahlulbait dan membersihkan kamu sebersih-bersihnya."

Quraish Shihab mengutip penafsiran Ibn Abbas yang menafsirkan ayat ini dengan cara mengemukakan kisah yang intinya ialah menujukan adanya sesuatu pesta yang dijadikan sebuah ajang pertemuan antara lelaki dan wanita zaman dahulu. Di dalam pesta tersebut, para wanita bersolek dengan cara mereka dengan tujuan agar lelaki yang memandangnya terpesona, sehingga terjadilah maksiat dan seks bebas di antara mereka. Jadi, tabarruj menurut Ibn Abbas adalah adanya perbuatan seorang wanita yang dengan sengaja atau dengan sadar dilakukan guna memancing dan syahwat lelaki yang memandangnya, entah itu melalui perhiasan maupun tingkah laku yang mereka perbuat. ${ }^{17}$

Dalam kamus Lisan al-'Arab, Ibnu Manzur menjelaskan bahwa "segala sesuatu yang nampak dengan jelas dan menonjol, maka hal itu disebut dengan "baraja", itulah alasan mengapa istana-istana yang megah disebut dengan "burujub", dikarenakan kemenonjolan, kejelasan dan ketinggiannya". Selanjutnya, Abu Ishaq mengatakan bahwa "tabarruj" adalah menampakkan perhiasan dan segala sesuatu yang dipertontonkan untuk

16 Syamsuddin.

${ }^{17}$ Muslih Muhaimin Seknun, "Eksploitasi Wanita Di Era Kontemporer:(Studi Analisa Tafsir Tabarruj Dalam Al-Qur'an)" (Jakarta: Fakultas Ushuluddin Dan Filsafat UIN Syarif Hidayatullah, 2018); Syaikh Ahmad Syakir, Mukhtashar Tafsir Ibnu Katsir Jilid 1, ed. Suharlan Agus M'mun (Jakarta: Darus Sunnah Press, 2016), http://inlislite.uin-suska.ac.id/opac/detail-opac?id=13880. 
mengundang syahwat lelaki. ${ }^{18}$ Sedangkan dalam kamus al-Munawir diartikan dengan kalimat mempertontonkan perhiasan. ${ }^{19}$

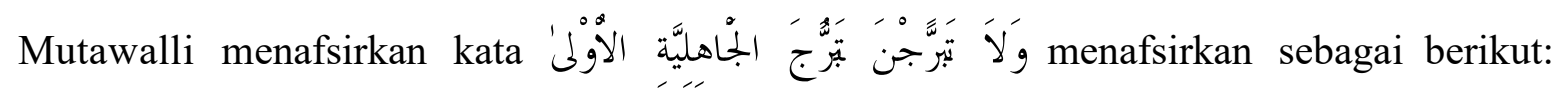
Istilah tabarruj memiliki kata dasar "al-burj” yang berarti benteng. Sehingga, makna tabarruj adalah keluar dari benteng yang ada dan sengaja memperlihatkan dirinya. Maksud yang terkandung dalam potongan ayat ini ialah: "janganlah kalian keluar dari benteng tutupan dan jangan pula kalian menampakkan perhiasan serta kemolekan yang wajib bagi kalian untuk

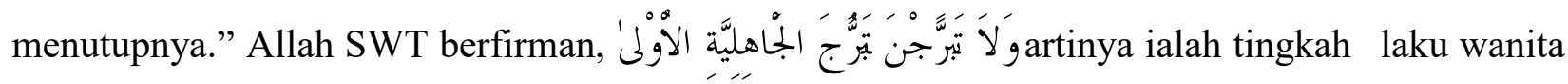
Arab pada masa Jahiliah (sebelum masuknya agama Islam). Wanita-wanita yang berstatus sebagai budak (bukan wanita merdeka) dengan sengaja menampakkan lekuk-lekuk tubuhnya, bahkan hampir saja disebut telanjang. Ironisnya mereka sama sekali tidak merasa rendah dengan sikap mereka yang demikian itu. Tradisi wanita demikian pernah dijumpai di daerah Afrika, yang mana juga dijadikan sebuah tradisi oleh mereka (wanita Afrika). ${ }^{20}$

Dalam tafsir Mafātihul Ghaib karya Imam Fakhruddin al-Razi, beliau berpendapat

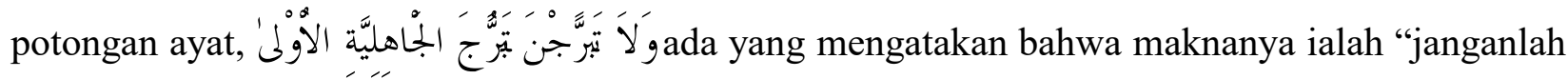
kalian membuka sebagian anggota tubuh kalian apalagi genit kepada kaum lelaki yang bukan mahram kalian". Tapi bisa jadi yang dimaksud ialah "janganlah kalian memperlihatkan perhiasan kalian.” Sedangkan, makna dari kata الجُاهليَّة الأولْلى menurut al-Razi setidaknya yaitu mengandung dua makna; yaitu orang yang berada pada zaman hidupnya Nabi Nuh AS sedangkan Jahiliah lain maksudnya adalah kaum yang ada setelahnya. Kedua, lafal yang dahulu pada ayat tersebut bukan bermakna yang pertama yang menghendaki makna yang lain, namun yang dimaksud adalah seperti tabarruj (berhias) nya orang-orang pada masa Jahiliah awal. ${ }^{21}$

Penulis juga mengutip tafsir Al-Azhar karya Hamka. Beliau menjelaskan bahwa adanya kaitan antara larangan tabarruj dengan perintah menegakkan salat dan zakat serta perintah Allah Swt dan Rasul-Nya yang kemudian menjadi kesatuan ayat. Hamka menafsirkan maksud dari ayat tersebut adalah larangan yang disebabkan karenan wanita-wanita Jahiliah awal. Hamka menafsirkan ketika mereka menghias dirinya yang bertujuan untuk tampil lebih cantik, agar terlihat lebih menonjol di antara yang lain, mempesona di mata orang yang memandangnya, laksana ketika mereka berhias seakan-akan memanggil-manggil meminta untuk dipegang oleh lawan jenis yang melihat keelokan tubuhnya. Adapun kaitannya dengan ayat selanjutnya tentang perintah menegakkan salat, membayar zakat serta mematuhi perintah Allah Swt dan Rasul-Nya yaitu, apabila ajaran dari Rasulullah Saw telah diterima dengan baik, maka akan muncul keimanan dari dalam diri mereka dan menjadi penangkal bagi tiap individu (wanita). Ketika mereka berhias, maka mereka dengan spontan melakukannya dengan cara yang sopan sesuai aturan Islam dan tidak mencolok seperti yang dilakukan wanita Jahiliah masa awal.

Selanjutnya Hamka juga berpendapat bahwa ayat tersebut tidak hanya berbicara tentang larangan, namun beliau menambahkan bahwa tidak adanya penjelasan atau keterangan yang

\footnotetext{
${ }^{18}$ Ibnu Manzur, Lisan Al-Arab (Cairo: Dar al-Ma'arif, n.d.).

${ }^{19}$ Ahmad Warson Munawwir, Al Munawwir Kamus Arab-Indonesia (Surabaya: Pustaka Progresif, 1997).

${ }^{20}$ Mutawalli Al-Sya'rawi, Tafsir Al-Sya'rawi (Majma' al-Buhuts al-Islamiyah, 1961).

${ }^{21}$ Fakhruddin Al-Razi, Mafatih Al-Ghaib (Bayrut: Dar al-Fikr, 1981).
} 
terdapat di dalam ayat ini tentang bagaimana mode atau tren pakaian, bentuk pakaian seperti apakah yang harus digunakan wanita, ataukan baju adat bangsa mana yang harus dipakai agar terhindar dari tabarruj. Ini menunjukkan bahwa ayat tersebut adalah pedoman yang dianjurkan untuk digunakan di setiap masa dan tempat yang terdapat masyarakat Islam hingga sekarang. Karena dalam ayat tersebut tidak dibicarakan apakah pakaian wanita harus yang bermodel Arab pada zaman Rasulullah Saw, ataukah baju model Prancis yang sekarang ini dianggap menjadi negara yang paling maju tentang mode pakaian ataukah baju adat Nusantara. Perlu ditekankan bahwasanya yang menjadi inti di sini adalah "janganlah berhias secara Jahiliah" melainkan, agar wanita masa sekarang berhias menurut garis kesopanan yang ada dalam ajaran agama Islam.

Tidak hanya sampai potongan ayat yang dibahas di atas, Hamka menambahkan tentang

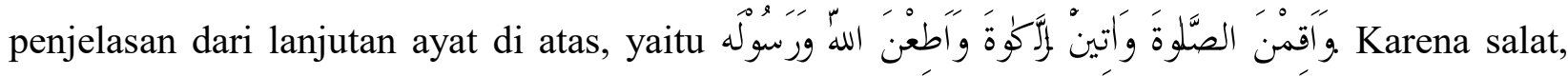
zakat dan ketaatan melaksanakan setiap perintah Allah Swt dan Rasul-Nya serta menghentikan yang dilarang, akan membawa pengaruh yang sangat besar terhadap cara pakaian dan cara berhias seorang wanita. Seperti yang disinggung di atas, bahwa ketaatan yang ia lakukan akan selalu meninggalkan bekas dalam kehidupan sehari-hari, termasuk cara berpakaian dan cara berhias seorang wanita. ${ }^{22}$

Dijelaskan pula dalam Al-Tahrīr wa Al-Tanwīr karya Ibnu 'Asyur, bahwa potongan ayat,

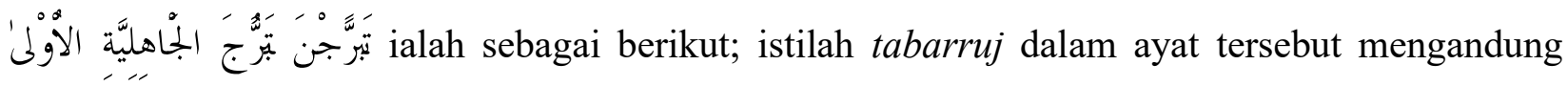
makna adanya seorang wanita yang menampakkan keindahan tubuh, pakaian, serta

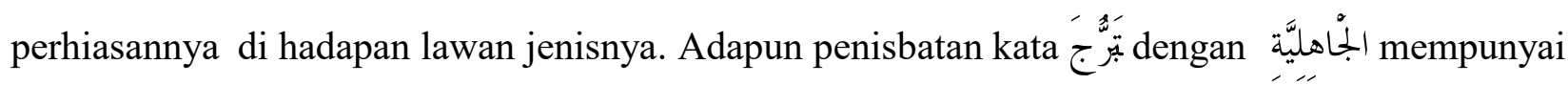
makna agar para wanita menjauhi cara menghias diri yang dilakukan secara berlebih-lebihan sebagaimana yang dahulu pernah dilakukan oleh golongan Jahiliah masa awal-awal. Tujuannya yaitu agar mereka senantiasa terjaga kehormatan dan kesuciannya serta terhindar dari hal-hal yang dilarang oleh Allah Swt. Larangan melakukan tabarruj juga berlaku untuk para wanita secara universal, karena pada saat ayat ini diturunkan di Madinah kala itu, ditemui beberapa wanita munafik yang faktanya masih melakukknya. Mereka belum dapat meninggalkan tradisi tabarruj yang pernah dilakukan pada zaman Jahiliah terdahulu. Maka dapat disimpulkan bahwa seruan Allah Swt dalam ayat ini juga bermaksud untuk mencegah semua kaum muslimah agar tidak lagi melakukan tradisi tabarruj seperti yang dilakukan oleh wanita pada masa Jahiliah awal-awal. ${ }^{23}$

\section{Asbāb al-Nuz̄ūl Mikro dan Makro}

Kondisi bangsa Arab pra-Islam dikenal dengan zaman kegelapan/Jahiliah (الجَاهلَّليَّة) yang mana wanita hidup dengan keadaan yang buruk serta ketaklukan kepada yang lebih tinggi derajatnya. Setiap keluarga yang melahirkan bayi wanita dipandang sebagai aib. Selain itu pembunuhan terhadap bayi-bayi wanita dengan cara penguburan hidup-hidup sudah menjadi hal yang lumrah

\footnotetext{
${ }^{22}$ Hamka, Tafsir Al-Azhar, Juz XXII (Jakarta: Pustaka Panjimas, 2002).

${ }^{23}$ Al-Tahir Ibnu 'Asyur, Al-Tahrīr Wa Al-Tanwīr Juz 12 (Tunisiyyah, 1984).
} 
dan ditemui di mana-mana kala itu. Alasan penguburan tersebut adalah untuk membebaskan orangtua dari beratnya beban finansial serta rasa malu karena melahirkan bayi wanita. ${ }^{24}$

Diceritakan pula oleh Quraish Shihab, pada zaman Jahiliah dahulu orang-orang yang memiliki harta banyak konon minum dengan gelas yang terbuat dari emas serta wanitawanitanya memakai perhiasan dari emas dan perak. Mereka juga memiliki banyak kuda-kuda pilihan yang dijadikan sebagai hewan peliharaan. Bahkan jauh sebelumya, beliau juga menjelaskan bahwa perilaku mereka yang demikian itu juga dituliskan dalam Perjanjian Lama, salah satu contohnya ialah kepercayaan mereka yang menyembah bintang dan memberikan anak kandung mereka sendiri sebagai persembahan tumbal. Contoh lain ialah mereka mempersembahkan "kasedoth" di tempat peribadatan yang diyakini suci. Yang dimaksud dengan "kasedoth" yakni wanita-wanita yang pekerjaannya ialah menjual dirinya (pelacur) mempergunakannya sebagai alat untuk memuaskan birahi lelaki. Lalu sebagai imbalannya, uang yang mereka peroleh akan dimasukkan untuk kas rumah peribadatan. ${ }^{25}$ Hal ini menunjukkan betapa buruknya citra wanita pada zama Arab Jahiliah dahulu.

Ada perbedaan pendapat mengenai kapan terjadinya peristiwa pada zaman Jahiliah yang menjadi sebab turunnya QS Al-Ahzab ayat 33. Antara lain:

Pertama, pendapat yang dikemukakan oleh al Kalbi, beliau menyatakan bahwa kejadian tabarruj terjadi di antara zaman Nabi Nuh AS dan Nabi Ibrahim AS. Diriwayatkan pula bahwa dahulu pakaian luar seperti jaket atau mantel yang digunakan para wanita Jahiliah awal terbuat dari mutiara yang sisi kanan dan kirinya sangat polos (tidak terjahit dan menyatu seutuhnya), sedangkan pakaian yang mereka kenakan sehari-hari biasanya terbuat dari bahan yang sangat tipis sehingga tubuh mereka tetap terlihat jelas meskipun mereka menggunakan pakaian. ${ }^{26}$

Kedua, pendapat yang dikemukakan oleh al-Thabari, beliau menyatakan bahwa kejadian itu terjadi diantara zaman Nabi Nuh AS dan Nabi Idris AS. Beliau meriwayatkan di antara zaman tersebut ditemui adanya dua kelompok anak Adam. Kelompok pertama tinggal di daerah lembah dan kelompok kedua tinggal di daerah gunung. Penduduk lelaki yang tinggal di daerah gunung tergolong orang-orang baik, namun penduduk wanita di kelompok mereka ialah wanita yang bertingkah laku buruk. Sedangkan penduduk lelaki yang tinggal di daerah lembah adalah yang buruk perilakunya, namun penduduk wanitanya bertingkah laku baik. Kemudian, datanglah iblis dalam wujud seorang pemuda mendekati seorang lelaki penduduk lembah, lalu lelaki tersebut mengupah iblis untuk menjadi seorang pelayan. Kemudian jelmaan lelaki tersebut menggunakan alat seperti seruling untuk mengembala dan dengan alat itu. Iblis mengeluarkan suara yang belum pernah terdengar hingga suara itupun sampai ke telinga orang-orang sekitar yang menyebabkan mereka kagum untuk mendengarnya. Mereka yang mendengar suara merdu tersebut akhirnya mengadakan hari raya agar mereka dapat berkumpul, lalu penduduk lelaki berhias untuk dipamerkan kepada wanita dan juga sebaliknya. Penduduk wanita juga berhias dengan tujuan yang sama yaitu untuk dipamerkan kepada lelaki. Seorang lelaki dari penduduk

\footnotetext{
${ }^{24}$ Bahtar Bahtar, "Eksploitasi Wanita Di Media Massa: Teori Perspektif Sosial Dan Komunikasi Islam," HUNAFA: Jurnal Studia Islamika 3, no. 3 (September 15, 2006): 275-86, https://doi.org/10.24239/JSI.V3I3.272.275-286.

${ }^{25}$ Muhammad Quraish Shihab, Membaca Sirah Nabi Muhammad Saw. Dalam Sorotan Al-Qur'an Dan Hadits-Hadits Shahih (Lentera Hati, 2011).

26 Imam Al-Qurthubi, Tafsir Al Qurthubi Jilid 2 (Jakarta: Pustaka Azzam, 2007), http://inlislite.uinsuska.ac.id/opac/detail-opac?id=5098.
} 
gunung lalu menyerbu para wanita saat perayaan. Ketika mereka melihat para wanita tersebut, mereka langsung mendatangi teman-temanya yang lain untuk mengabarkan adanya pesta tersebut kepada mereka. Dengan adanya perayaan tersebut, maka terjadilah perzinaan di antara mereka. ${ }^{27}$

Dan yang ketiga, diceritakan pula bahwa pada zaman dahulu, wanita-wanita Arab menggunakan baju dengan dada yang terbuka (tidak menutupi daerah leher dan dada). Penutup kepala yang mereka kenakan juga selalu diurai ke belakang yang menyebabkan terlihatnya kedua leher, telinga, dan anting-anting yang mereka gunakan. ${ }^{28}$

Dari beragam asbāb al-nuzūl yang penulis paparkan di atas, tergambar jelas bahwa ayat ini turun terkait dengan tuntunan kesopanan yang dianjurkan untuk istri-istri Nabi pada waktu itu agar tidak berperilaku seperti wanita wanita Jahiliah zaman dulu. Namun makna ahlu al-bait pada ayat tersebut ditafsirkan oleh para mufasir yang secara ringkas dapat disimpulkan universal untuk semua muslimah hingga hari ini.

Latar belakang mikro turunnya ayat tersebut juga sesuai dengan kondisi bangsa Arab yang mana di masa itu banyak wanita Jahiliah yang melakukan tindakan tabarruj. Salah satu contohnya adalah ketika pada masa Arab Jahiliah dan awal masa Islam, para wanita di Jazirah Arab menggunakan busana yang pada dasarnya mengundang syahwat lelaki, selain kegunaannya untuk mengurangi udara panas yang menjadi iklim daerah padang pasir. Wanita Arab dulu sebenarnya juga memakai kerudung (penutup kepala), namun hanya diletakkan di atas kepala dan dibiarkan terulur kebelakang, sehingga menyebabkan bagian dada dan kalung yang mereka gunakan tetap terlihat scara jelas. Bahkan terkadang, tidak jarang dari bagian buah dada mereka dapat terlihat dikarenakan longgarnya baju yang mereka kenakan. Telinga mereka yang dihiasi anting dan leher mereka yang dihiasi dengan kalung sengaja ditampakkan. Selain itu, kaki dan tangan mereka juga dihiasi dengan gelang yang mana jika kaki mereka berjalan, akan menimbulkan bunyi nyaring dari gelang kakinya dan membuat mereka menjadi objek perhatian banyak orang disekitar mereka. Kuku tangan serta tangan mereka juga dihiasi dengan kuteks (pewarna kuku). Alis mereka juga dicabut agar terlihat rapi serta pipi mereka juga dimerahkan untuk menarik perhatian. ${ }^{29}$

Pada masa Jahiliah awal, wanita hanya dinilai sebagai alat untuk memuakan syahwat kaum lelaki. Karenanya, wanita dinilai sangatlah rendah. Dampak buruk dari penilaian ini sangatlah nyata dalam kekacauan pola hubungan seksual dalam masyarakat Arab waktu itu. Ironisnya, segala hal diperbolehkan, sepanjang hal tersebut menguntungkan bagi kaum lelaki, khususnya untuk mereka yang berkuasa zaman dulu. Oleh karena itu, masyarakat Arab sering mengadakan pesta-pesta gemerlap dengan menghiasi kaum wanita yang dijadikan untuk kenikmatan kaum lelaki yang memandangnya, sekaligus untuk mengundang terjadinya kemaksiatan, yang mana wanita diperdagangkan (prostitusi atau pelacuran). Sudah menjadi tabiat kala itu, kaum-kaum penguasa atau saudagar kaya menjamu tamu kehormatannya dengan

27 Abu Ja'far Muhammad Bin Jarir Ath-Thabari, Tafsir Ath-Thabari Jilid 21: Surah: Al Ahzaab, Saba' Faathir, Yaasiin Dan Ash-Shaaffaat (Jakarta: Pustaka Azzam, 2009), http://inlislite.uin-suska.ac.id/opac/detailopac?id=11546.

28 Murthada Muthahhari, Wanita [Dan] Hijab (Jakarta: Lentera Basritama, 2000), https://opac.perpusnas.go.id/DetailOpac.aspx?id=385486.

${ }^{29}$ Muthahhari. 
jamuan-jamuan perempuan cantik fisiknya (bukanlah cantik dari kepribadian melainkan cantik yang dinilai dari wajah dan kemolekan tubuhnya). ${ }^{30}$

\section{Analisis Intratekstualitas}

Setelah melakukan analisis linguistik, maka dalam pendekatan ma'nā-cum-maghzā selanjutnya dilakukan intratekstualitas, yaitu membandingkan penggunaan kata yang sedang ditafsirkan dengan penggunaan kata yang lain nan terdapat dalam al-Qur'an. Adapun ayat lain yang menyebutkan tentang tabarruj adalah QS An-Nur: 60.

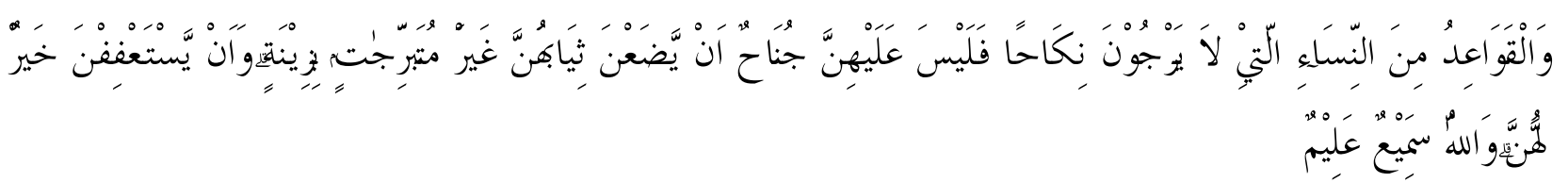

Artinya: Para wanita tua yang telah berhenti (dari haid dan mengandung) yang tidak lagi berhasrat menikah, tidak ada dosa bagi mereka menanggalkan pakaian (luar) dengan tidak (bermaksud) menampakkan perhiasan. Akan tetapi, memelihara kehormatan (tetap mengenakan pakaian luar) lebih baik bagi mereka. Allah Swt Maha Mendengar lagi Maha Mengetahui.

Dalam Lisan al-'Arab dikutip: "at-tabarruju: Izhāru al-zīnati wa mā yustad'ā bih̄ syahwat ar-rijāl', yang artinya tabarruj adalah pertunjukan perhiasan dan apa saja yang dengannya syahwat kaum lelaki tertarik". ${ }^{31}$ Menurut bahasa, Ahsin W. Hafidz menjelaskan dalam Kamus Ilmu al-Qur'an, tabarruj mempunyai arti berhias diri dan bertingkah laku. Adapun yang dimaksud dengan larangan tersebut adalah larangan terhadap istri-istri Nabi untuk berhias diri dan bertingkah laku (dengan menampakkan atau membuka aurat) seperti cara berhias dan bertingkah laku wanita-wanita masa Jahiliah. Demikian harusnya kaum wanita muslimah sekarang hendaknya meneladani yang telah diajarkan Allah kepada para istri Rasulullah SAW. ${ }^{32}$

Dalam al-Misbah, kata متبرِجَت terambil dari kata tabarruj yaitu keterbukaan. Larangan tabarruj di sini berarti larangan menampakkan "perhiasan" dalam pengertiannya yang umum yang biasanya tidak ditampakkan oleh wanita-wanita baik, atau memakai sesuatu yang tidak wajar dipakai. Seperti ber-make up secara berlebihan, atau berjalan dengan berlenggak-lenggok dan sebagian. menampakkan sesuatu yang biasanya tidak ditampakkan, kecuali kepada suami yang dapat menimbulkan rangsangan atau mengakibatkan gangguan lawan jenis. Ayat ini tertuju kepada wanita yang sudah menopause, sehingga tentu saja yang muda lebih dilarang. ${ }^{33}$

Adapun perbedaan antar ayat yang memuat konsep tabarruj di atas, adalah jika dalam QS Al-Ahzab ayat 33, diartikan sebagai larangan umum bagi muslimah untuk ber-tabarruj, sedangkan pada QS An-Nur ayat 60, terdapat pengkhususan bagi wanita yang sudah mengalami monopouse, atau dalam keadaan darurat lainnya, namun di akhir ayat tetap dianjurkan bagi

${ }^{30}$ Wati and Saputra, “The Concept of Tabarruj in the Qur'an According to Muslim Commentators.”

${ }^{31}$ Manzur, Lisan Al-Arab.

32 Ahsin W. Al-Hafidz, Kamus Ilmu AlQuran (Jakarta: Amzah, 2005), https:/opac.perpusnas.go.id/DetailOpac.aspx?id=438068.

${ }^{33}$ Asikh, "Makna Tabarruj Menurut M. Quraish Shihab Dalam Tafsir Al-Miṣbāh Dan Relevansinya Di Era Sekarang”; M Quraish Shihab, “Tafsir Al-Misbah,” Jakarta: Lentera Hati 2 (2002). 
mereka untuk menghindari perilaku tabarruj tersebut. Demikian sebagaimana terdapat dalam Tafsir Jalalain. ${ }^{34}$

\section{Analisis Intertekstualitas}

Analisis intertekstualitas adalah tindakan menghubungkan dan membandingkan antara ayat al Qur'an dengan teks-teks lain yang ada di sekitarnya (selain al-Qur'an). Salah satu teks yang sering digunakan dalam metode ini adalah hadis Nabi. Dalam kaitannya dengan konsep tabarruj sebagaimana yang terdapat pada QS Al Ahzab ayat 33, peneliti turut menggunakan hadis Nabi sebagai teks pembanding, yaitu hadis dalam Musnad Imam Ahmad nomor 6554 yang berbunyi:

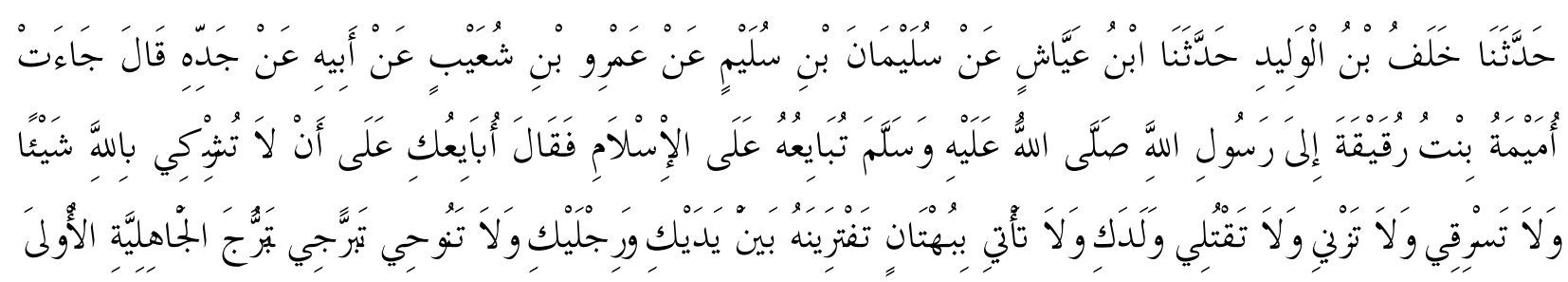

Artinya: "Telah menceritakan kepada kami Khalaf bin Walid telah menceritakan kepada kami Ibnu 'Ayyasy dari Sulaiman bin Sulaim dari 'Amru bin Syu'aib dari bapaknya dari kakeknya, dia berkata; Umaimah bin Ruqoiqoh datang kepada Rasulullah untuk berbaiat kepada Islam, maka Rasul pun bersabda: "Aku membaiatmu untuk tidak menyekutukan Allah dengan yang lain, untuk tidak mencuri, tidak berzina, tidak membunuh anakmu, tidak berbuat dusta yang kau adaadakan antara tangan dan kakimu, untuk tidak meratapi (mayit), dan untuk tidak berhias dan bertingkah laku seperti orang-orang jahiliah terdahulu.",35

Dilihat dari konteks hadis di atas, anjuran untuk menghindari tabarruj telah menjadi bagian dari ucapan pembaiatan yang dilakukan oleh Rasulullah kepada generasi awal umat Islam. Ungkapan tabarruj sendiri diartikan sebagai cara menghias diri dan bertingkah laku seperti orang Jahiliah di zaman dahulu. Atau dengan kata lain, budaya tabarruj adalah bagian buruk dari tradisi Jahiliah yang dihilangkan dengan kedatangan Islam.

Selain hadis di atas, Islam telah melarang wanita melakukan tabarruj (menampakkan perhiasannya). Sabda Rasulullah Saw sebagaimana yang termaktub dalam Musnad Imam Ahmad nomor 3423 sebagai berikut:

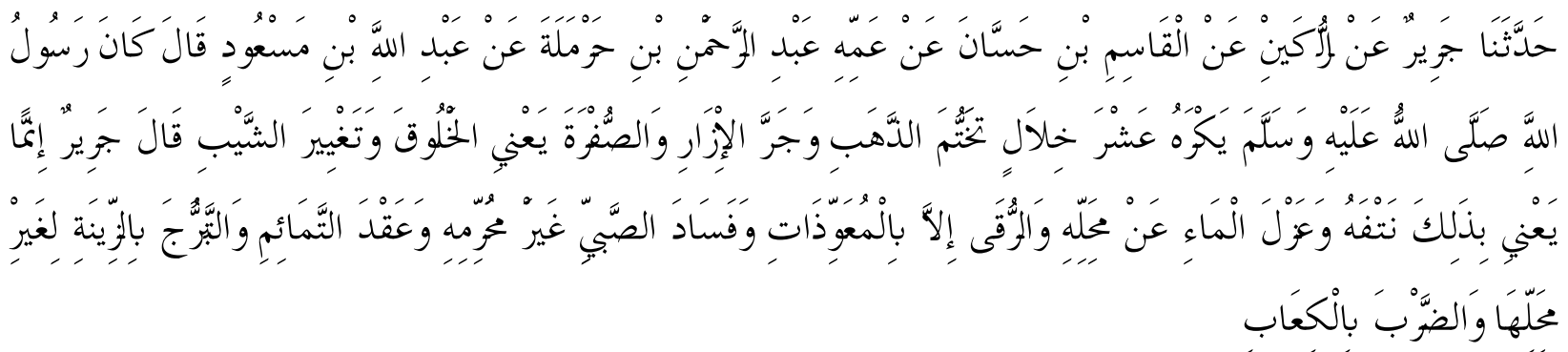

Artinya: "Telah menceritakan kepada kami [Jarir] dari [Ar Rukain] dari [Al Qosim bin Hassan] dari pamannya yakni [Abdurrahman bin Harmalah] dari [Abdullah bin Mas'ud] berkata; Rasulullah shallallahu 'alaihi wasallam membenci sepuluh perkara; memakai cincin emas,

\footnotetext{
${ }^{34}$ Jalaluddin As-Suyuthi and Jalaluddin Al-Mahalli, “Tafsir Jalalain,” Surabaya: Imaratullah, 2003.

35 "Musnad Ahmad," CariHadis.com, accessed December 15, 2021, https://carihadis.com/Musnad_Ahmad/.
} 
memanjangkan kain, memakai warna kuning maksudnya pakaian, mengubah uban, Jarir berkata; Yang dimaksud adalah mencabutnya, menumpahkan air (sperma) dari tempatnya, ruqyah selain dengan mu'awwidzatain (Surat Al Falaq dan An Naas), merusak bayi yang tidak sampai hukum haram, mengalungkan jimat, tabarruj (menampakkan) perhiasan selain pada tempatnya dan menghentak-hentakkan tumit. ",36

Dalam hadis ini, disebutkan 10 perkara yang dibenci oleh Rasulullah Saw, yang mana salah satunya yakni tabarruj (menampakkan) perhiasan selain pada tempatnya dan menghentakhentakkan tumit. Melalui penjelasan dua hadis di atas, dapat penulis simpulkan bahwa tabarruj merupakan gaya berbusana ataupun sikap wanita Jahiliah yang sengaja diperlihatkan, termasuk tindakan berdandan untuk seseorang yang bukan muhramnya adalah menjadi hal yang harus dijauhi oleh umat Islam.

\section{Signifikansi Dinamis dan Relevansinya dalam Kehidupan Kekinian}

Untuk mendapatkan signifikansi kontemporer ayat, langkah-langkah yang harus ditempuh antara lain adalah; (a) menentukan kategori ayat, (b) reaktualisasi dan kontekstualisasi signifikansi ayat, (c) mencari makna simbolik ayat, dan (d) memperkuat signifikansi ayat dengan disiplin keilmuan yang lain. ${ }^{37}$

Selanjutnya dalam hal kategori ayat, sebagian besar ulama membagi al- Qur'an menjadi tiga bagian, yaitu, ayat-ayat ketauhidan, hukum, dan kisah kenabian. Sedangkan dalam ayat-ayat Hukum, Abdullah Saed, sebagaimana yang dikutip oleh Sahiron, membaginya dalam lima hierarki nilai, yakni; (a) obligatory values (nilai-nilai kewajiban), (b) fundamental values (nilainilai dasar kemanusiaan), (c) protectional values (nilai-nilai proteksi), (d) implemental values (nilai-nilai yang diimplementasikan), dan (e) instructional values (nilai-nilai instruksi) ${ }^{38}$

Melihat isi yang disampaikan dalam QS Al-Ahzab ayat 33, peneliti mengambil kesimpulan bahwa ayat ini merupakan salah satu ayat-ayat hukum. Sedangkan dalam hierarki nilainya, ayat ini mengandung protectional values sekaligus instructional values. Fundamental values ayat ini adalah menjaga keamanan wanita dari perilaku pelecehan serta menjauhkan umat Islam dari pengaruh buruk tradisi Jahiliah. Sedangkan instructional values ayat ini terdapat pada dua hal yang saling berkaitan, yaitu larangan untuk keluar rumah, serta meniru cara berpakaian (menghiasi diri) seperti masyarakat Arab pra-Islam.

Pada nilai yang pertama, ayat ini tidak perlu dikontekstualisasikan karena pengamalan nilai tersebut berlaku sepanjang zaman dan bersifat universal. Sedangkan pada nilai kedua, sangat bergantung pada kondisi zaman dan tempat ayat tersebut diturunkan, sehingga bisa ditambah, dikurangi maupun dimodifikasi sesuai dengan tuntutan era kekinian. Proses modifikasi tersebut tentunya harus memperhatikan nilai universal ayat tersebut. Hemat penulis, potongan ayat

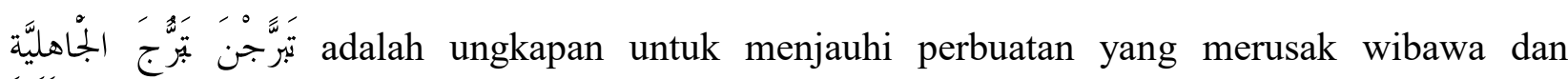
kehormatan diri sendiri sebagaimana terjadi pada masyarakat yang belum mengenal nilai dan

36 "Musnad Ahmad."

${ }^{37}$ Syamsuddin, Pendekatan Ma'na-Cum-Maghza Atas Al-Qur'an Dan Hadis: Menjawab Problematika Sosial Keagamaan Di Era Kontemporer.

${ }^{38}$ Syamsuddin. 
pengetahuan. Dari pemahaman inilah, dapat disimpulkan bahwa makna larangan tabarruj tidak hanya sekadar cara berpakaian seseorang, perilaku menggoda di luar rumah, ataupun sengaja menampakkan apa yang dikenakan. Tetapi anjuran untuk menjadi pribadi muslim yang beretika, terhormat, dan berwibawa. Tentunya hal tersebut tidak hanya berlaku kaum wanita, akan tetapi juga ditujukan untuk kaum lelaki.

Selanjutnya, penulis menyimpulkan bahwa ada dua hal signifikansi dinamis ayat ini yang saling berkaitan satu sama lain. Yakni: (1) anjuran untuk menjaga kehormatan dan keselamatan kaum wanita, (2) tuntutan untuk menjadi pribadi muslim yang beretika dan berwibawa. Kedua makna signifikansi dinamis ayat tersebut memiliki relevansi apabila dikontekstualisasikan dalam era kekinian. Seperti yang telah menjadi pengetahuan umum, bahwa cara berperilaku manusia modern sejatinya tidak jauh berbeda dari dengan manusia di masa Jahiliah. Hal yang pada kemudian hari menyebabkan banyak ulama mengategorikannya sebagai bentuk Jahiliah baru. Selain itu tantangan yang ada dalam dunia modern jauh lebih kompleks. Semisal jika zaman dahulu sebagaimana yang diceritakan dalam ayat, perilaku tabarruj dimaknai sebagai cara menghias diri untuk menggoda lawan jenis (atau dalam kondisi sekarang lebih akrab dikenal dengan istilah tebar pesona) di luar rumah sudah tidak cocok lagi dengan kondisi kekinian. Hal ini dikarenakan pada konteks kekinian, tebar pesona bisa dilakukan di mana saja dan kapan saja melalui berbagai media sosial yang ada.

Dalam hal tuntutan untuk memiliki kepribadian yang beretika, terhormat, dan berwibawa turut menjadi problem bagi manusia di era modern. Beberapa golongan anak muda tidak segansegan mempertontonkan hal tidak senonoh semisal memamerkan auratnya, ataupun melakukan adegan yang mengarahkan pada aktifitas seksual. ${ }^{39}$ Perbuatan-perbuatan tersebut menjadikan mereka sebagai target pelecehan ataupun tindakan kekerasan lainnya. Namun potensi yang membahayakan dirinya tersebut dengan mudah diabaikan demi mencapai predikat viral di media sosial.

Berpijak dari fenomena tersebut, makna larangan tabarruj sebagaimana yang dimaksud QS Al-Ahzab ayat 33 tidak hanya dimaknai secara literal sebagai larangan keluar rumah dan menghias diri serta berperilaku sebagaimana di zaman Jahiliah bagi kaum muslimah. Namun sebagai tuntutan bagi seluruh umat lelaki dan wanita untuk menjaga keamanan dan kehormatan, sekaligus menjadi pribadi muslim yang beretika, terhormat, dan berwibawa.

\section{Simpulan}

Dari berbagai ulasan yang telah dipaparkan di atas, kesimpulan yang dapat penulis ambil antara lain ialah; budaya tabarruj pada awalnya adalah budaya Jahiliah yang ditentang dan dihapus karena kedatangan Islam. Budaya ini tidak hanya meruntuhkan kehormatan wanita, melainkan menimbulkan budaya eksploitasi kaum lelaki terhadap wanita. Tabarruj dalam ma'nā al-târīkhī diartikan sebagai cara berhias, berpakaian, serta perilaku berlebihan yang mengundang syahwat bagi lawan jenis yang bukan mahram ataupun dengan tujuan untuk memamerkan kekayaan. Selanjutnya, maghzā al-tārīkhī yaitu; Pertama, larangan tabarruj bertujuan untuk

39 Sulung Lahitani, "8 Potret Orang Yang Lakukan Segala Cara Demi Viral Di Medsos - Citizen6 Liputan6.Com," Liputan6.com, accessed December 15, 2021, https://www.liputan6.com/citizen6/read/4453263/8potret-orang-yang-lakukan-segala-cara-demi-viral-di-medsos. 
melindungi kaum muslimah dari bahaya pelecehan seksua; yang terjadi dalam masyarakat yang tidak kondusif. Kedua, larangan tabarruj bertujuan untuk menghindarkan umat Islam dari pengaruh buruk tradisi Arab Jahiliah. Ketiga, larangan tabarruj bertujuan sebagai proses identifikasi kaum muslim di tengah masyarakat yang tidak kondusif. Yang terakhir pada bagian signifikansi dinamis dan relevansi QS Al-Ahzab ayat 33 dalam konteks kekinian (maghzā al$\bar{a} y a h)$ adalah adanya dua hal yang saling berkaitan satu sama lain, yaitu: (a) anjuran untuk menjaga kehormatan dan keselamatan kaum wanita, (b) serta tuntutan untuk menjadi pribadi muslim yang beretika dan berwibawa.

\section{Referensi}

Afifah, Zuhroful. "Tafsir Larangan Bersolek (Tabarruj) Dalam Surah Al-Ahzab: 33 Menurut atThabari." UIN Sunan Ampel Surabaya, 2014.

Al-Azizi, Abdul Syukur. Kitab Lengkap Dan Praktis Fiqh Wanita. NOKTAH, 2017.

Al-Barudi, Imad Zaki. Tafsir Al-Qur'an Wanita. Pena Pundi Aksara, 2007.

Al-Hafidz, Ahsin W. Kamus Ilmu AlQuran. Jakarta: Amzah, 2005. https://opac.perpusnas.go.id/DetailOpac.aspx?id=438068.

Al-Qurthubi, Imam. Tafsir Al Qurthubi Jilid 2. Jakarta: Pustaka Azzam, 2007. http://inlislite.uinsuska.ac.id/opac/detail-opac?id=5098.

Al-Razi, Fakhruddin. Mafatih Al-Ghaib. Bayrut: Dar al-Fikr, 1981.

Al-Sya'rawi, Mutawalli. Tafsir Al-Sya 'rawi. Majma' al-Buhuts al-Islamiyah, 1961.

Ali, Muhammad Ibnu Muhammad. "Hijab Risalah Tentang Aurat." Yogyakarta: Pustaka Sufi, 2002.

As-Suyuthi, Jalaluddin, and Jalaluddin Al-Mahalli. "Tafsir Jalalain.” Surabaya: Imaratullah, 2003.

Asikh, Muhamad Nur. "Makna Tabarruj Menurut M. Quraish Shihab Dalam Tafsir Al-Miṣbāh Dan Relevansinya Di Era Sekarang.” UIN Walisongo Semarang, 2018.

Ath-Thabari, Abu Ja'far Muhammad Bin Jarir. Tafsir Ath-Thabari Jilid 21 : Surah: Al Ahzaab, Saba' Faathir, Yaasiin Dan Ash-Shaaffaat. Jakarta: Pustaka Azzam, 2009. http://inlislite.uin-suska.ac.id/opac/detail-opac?id=11546.

Bahtar, Bahtar. "Eksploitasi Wanita Di Media Massa: Teori Perspektif Sosial Dan Komunikasi Islam." HUNAFA: Jurnal Studia Islamika 3, no. 3 (September 15, 2006): 275-86. https://doi.org/10.24239/JSI.V3I3.272.275-286.

binti Nordin, Sarimah, Sulaiman Shakib bin Mohd Noor, and Mohd Al'Ikhsan bin Ghazali. "Fenomena Tabarruj Masa Kini Dalam Kalangan Wanita Muslimah." In Proceedings of the International Conference on Education towards Global Peace, 2016.

Firmansyah, F. "Konsep Tabarruj Dalam Hadis: Studi Tentang Kualitas Dan Pemahaman Hadis Mengenai Adab Berpakaian Bagi Wanita.” AT-TAHDIS: Journal of Hadith Studies 1, no. 2 (July 1, 2017). http://jurnal.uinsu.ac.id/index.php/attahdits/article/view/711.

Hamka. Tafsir Al-Azhar, Juz XXII. Jakarta: Pustaka Panjimas, 2002.

Ibnu 'Asyur, Al-Tahir. Al-Tahrīr Wa Al-Tanwīr Juz 12. Tunisiyyah, 1984.

Lahitani, Sulung. "8 Potret Orang Yang Lakukan Segala Cara Demi Viral Di Medsos - Citizen6 
Liputan6.Com.” Liputan6.com. Accessed December 15, 2021. https://www.liputan6.com/citizen6/read/4453263/8-potret-orang-yang-lakukan-segala-carademi-viral-di-medsos.

Manzur, Ibnu. Lisan Al-Arab. Cairo: Dar al-Ma'arif, n.d.

Munawwir, Ahmad Warson. Al Munawwir Kamus Arab-Indonesia. Surabaya: Pustaka Progresif, 1997.

"Musnad Ahmad.” Accessed December 15, 2021. https://carihadis.com/Musnad_Ahmad/.

Muthahhari, Murthada. Wanita [Dan] Hijab. Jakarta: Lentera Basritama, 2000. https://opac.perpusnas.go.id/DetailOpac.aspx?id=385486.

Nur Azmi, Vera. "Makna Tabarruj Perspektif Hadits Dalam Kitab Syarah Shahih Muslim Karya Imam An-Nawawi (631-676 H.)." Jurnal Penelitian Ilmu Ushuluddin 2, no. 2 (2022): 21834. https://doi.org/10.15575/JPIU.13591.

Seknun, Muslih Muhaimin. "Eksploitasi Wanita Di Era Kontemporer:(Studi Analisa Tafsir Tabarruj Dalam Al-Qur'an)." Jakarta: Fakultas Ushuluddin Dan Filsafat UIN Syarif Hidayatullah, 2018.

Shihab, M Quraish. “Tafsir Al-Misbah.” Jakarta: Lentera Hati 2 (2002).

Shihab, Muhammad Quraish. Membaca Sirah Nabi Muhammad Saw. Dalam Sorotan Al-Qur'an Dan Hadits-Hadits Shahih. Lentera Hati, 2011.

Sudariyah, Sudariyah. "Konstruksi Tafsir Al-Qur'anul Majid An-Nur Karya M Hasbi AshShiddieqy." SHAHIH: Journal of Islamicate Multidisciplinary 3, no. 1 (June 10, 2018): 93106. https://doi.org/10.22515/SHAHIH.V3I1.1282.

Syahdan, Tezar Alfi. "Pemahaman Dan Pengalaman Mahasiswa Fakultas Ushuluddin Dan Filsafat UIN Syarif Hidayatullah Jakarta Tahun 2011 (Studi Kasus Hadis Tabarruj).” UIN syarif Hidaytullah Jakarta: Fakultas Ushuluddin Dan Filsafat, 2011, 2011. https://repository.uinjkt.ac.id/dspace/handle/123456789/1457.

Syakir, Syaikh Ahmad. Mukhtashar Tafsir Ibnu Katsir Jilid 1. Edited by Suharlan Agus M'mun. Jakarta: Darus Sunnah Press, 2016. http://inlislite.uin-suska.ac.id/opac/detailopac?id=13880.

Syamsuddin, Sahiron, ed. Pendekatan Ma'na-Cum-Maghza Atas Al-Qur'an Dan Hadis: Menjawab Problematika Sosial Keagamaan Di Era Kontemporer. Yogyakarta: Asosiasi Ilmu Alquran \& Tafsir se-Indonesia, 2020. http://digilib.uinsuka.ac.id/id/eprint/40730/1/MAGNA CUM MAGHZA.pdf.

Wati, Mirna, and Hasep Saputra. "The Concept of Tabarruj in the Qur'an According to Muslim Commentators." AJIS: Academic Journal of Islamic Studies 3, no. 2 (December 30, 2018): 163-90. https://doi.org/10.29240/AJIS.V3I2.577. 